\title{
DECLINE IN UPLAND SANDPIPER POPULATIONS: HISTORY AND INTERPRETATIONS
}

\section{STUART HOUSTON, 863 University Drive, Saskatoon, SK S7N 0J8}

The Upland Sandpiper, a quintessential species of North American grasslands, was once common, and in some places abundant. How numerous was it on the Canadian prairies and elsewhere? How has it fared since Roberts reported the "sad tale of the wanton destruction of a valuable and once abundant bird that resulted in its almost complete extermination." 49

A more intriguing question has no obvious answer. Of the two waders that faced extirpation, why was the Upland Sandpiper and not the Eskimo Curlew the species to survive, when the breeding grounds of the curlew were remote and presumably subject to fewer harmful influences than those of the Upland Sandpiper?

Although most evidence is anecdotal, early explorers and naturalists have left us some useful information concerning the initial abundance of the Upland Sandpiper. For example, they used descriptive terms such as"very abundant", "extremely abundant", and "exceedingly abundant", to indicate high population densities at the very top of the rough numbers ranking. Such descriptions were so consistent that it is difficult to accuse any one observer of exaggeration (Table 1).

Early observers did not provide absolute numbers of birds observed. Yet a few precious observations provided information concerning numbers per unit distance or related the prevalence of Upland Sandpipers to that of other species. On Simcoe Island in Lake Ontario near Kingston in 1897-1898, Upland Sandpipers were as common as Eastern Meadowlarks, with 20 pairs in $3 \mathrm{~km} .{ }^{47}$ Two of the most useful reports are from J.A.
Allen and Elliott Coues, both of whom visited North Dakota in 1873. "Very common ... east of the Yellowstone, ... outnumbers all the other Grallae [Suborder Charadrii] together."2 Thus, Upland Sandpipers outnumbered other sandpipers, plovers, godwits, curlews, phalaropes, avocet and willet, all combined. "We can scarcely cross a piece of prairie, or travel a mile along the roads anywhere, without seeing it. ... I have often seen a dozen or twenty overhead at once, all from a little spot only a few acres in extent." ${ }^{19}$ Near Wauchope, in southeastern Saskatchewan, in the 1880s, ". . . a bird could be flushed every hundred yards or so almost anywhere."45 At Tregarva, north of Regina, in the first decade or two after 1900, Norman Clarke reported a pair every $3 \mathrm{~km} .{ }^{6}$ In 1892 at Red Deer, Alberta, "this sandpiper and the Western Meadowlark were about in the same numbers." 22

Initially, ranching was fully compatible with the Upland Sandpiper, as noted by Cooke. ${ }^{17}$ Before most of the original grassland was broken the Upland Sandpiper had nested over the entire state of South Dakota. ${ }^{44}$ Loss of habitat from the breaking of native grassland by the steel plow caused an immediate decline in numbers in the first decade after settlement. Roberts reported a sudden decline in southern Minnesota between 1895 and 1900; for example, he found the species "present everywhere" in Jackson and Pipestone counties in southwestern Minnesota in 1893, but "largely gone" in 1899.49 In both Minnesota and Alberta (see below), the timing of the population declines at the very end of the nineteenth century implicates conversion of grassland habitat as a primary factor in this decline. 
Table 1: Abundance in selected regions of North America, progressing to west and north

\section{LOCATION}

DATE

Michigan

Wisconsin

s. Minnesota

1870

lowa, Minnesota 1870s

N. Dakota, Cando 1890-1896

S. Dakota, Ft.

Sisseton

w. N. Dakota, e. 1873

Montana

Nebraska

1877

Kansas

Colorado,

e. Rocky Mts.

s. Manitoba,

Red River

Manitoba,

Carberry

Manitoba,

Treesbank

Manitoba,

Carberry

Manitoba,

Shoal Lakes

Saskatchewan, $\quad$ 1895-1900

Prince Albert,

Kinistino

s. Canadian prairies to 1900

Alberta, Red Deer 1892

\section{EARLY STATUS SOURCE}

abundant

Barrows $1912^{4}$

abundant

Hoy $1852^{32}$

Kumlein \& Hollister $1903^{38}$

exceedingly

abundant

very abundant Krider $1879^{37}$

abundant

Judd $1917^{36}$

very abundant

McChesney $1879^{41}$

very common

Allen $1874^{2}$

exceedingly

abundant

abundant

Goss $1886^{29}$

breeds

abundantly

extremely

abundant

extremely

abundant

very plentiful

breeds

abundantly

very common

exceedingly

Coubeaux $1900^{18}$

abundant

abundant

abundant
Criddle $1929^{21}$

Taverner $1919^{53}$

Macoun $1900^{40}$

Cooke $1897^{16}$

Coues $1878^{20}$

Seton $1909^{51}$

Christy $1885^{15}$

Farley $1932^{22}$ 


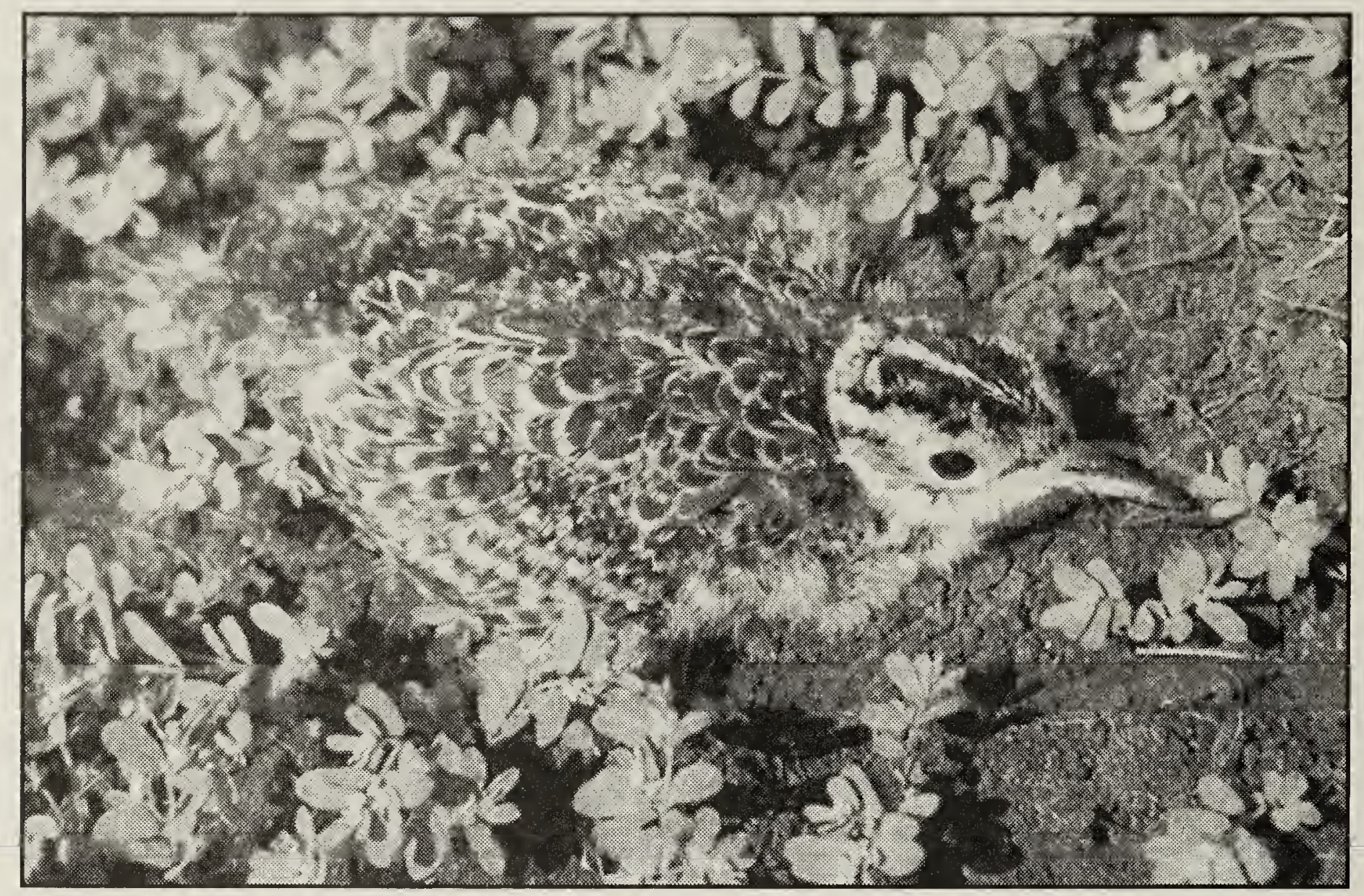

\section{Young Upland Sandpiper}

Another major factor in the initial decline of the Upland Sandpiper was the unmanaged and unregulated harvest for food, during spring and fall migration, during the summer, and on its "wintering" grounds in Argentina. "... one of the most luscious morsels to delight the epicurean palate," it was "destroyed by hundreds of thousands" and thus "nearly extirpated from the land." ${ }^{26}$ Coues also reported that it was "A prime game bird, wild and difficult to secure, best hunted from a carriage, and capital for the table ... tender and well-flavored." When the late Fred Langstaff (pers. comm.) settled on a farm in the Wallace district northeast of present Yorkton, Saskatchewan, in 1892, Upland Sandpipers were one of the most plentiful birds, and in spring and summer were a food source for newly-arrived settlers. Specific localities are rarely mentioned, but at least 152 Upland Sandpipers were shot on one small sandy prairie at the northern edge of Minneapolis, 27 July - 13 August $1874 . .^{49}$ In April 1899, one man in southern Louisiana shot 117 in one day. ${ }^{17}$ At Rock County in north-central Nebraska "they used to be shot for market straight through the nesting season." ${ }^{5}$ In 1890, two game dealers in Boston received over 9000 Upland Sandpipers for sale. ${ }^{39}$ At that time, they fetched a high price, "\$1.25 a dozen on the
Photo by G. J. Smith

St. Louis market," 55 a price roughly comparable to that of Passenger Pigeons 10 to 20 years earlier. ${ }^{50}$

"About 1880, when the supply of Passenger Pigeons began to fall ... the destruction of the Upland Plover began in earnest. The price increased. In the spring migration the birds were met by a horde of market gunners, shot, packed in barrels and shipped to the cities. There are tales of special refrigerator cars sent out to the prairie regions ... [to] ship plover and curlews by the carload to the Chicago market." ${ }^{25}$ According to Oberholser, 1870 through 1900 were the years of "rampant market hunting" in Texas. ${ }^{43}$ In Wisconsin, it was "little molested until it became generally known that it was one of our best table birds, and consequently brought a good price in the city markets. ... slaughtered both spring and fall in great numbers ... abominable practice of hunting with dogs for market ... has been to a great extent stopped, but entirely too late to save more than a remnant." ${ }^{38}$ In 1923, two men shot 68 Upland Sandpipers in one hour on the prairie a few miles south of Fort Worth, Texas. Their automobile engine never stopped and their gun barrels got hot. ${ }^{30}$ Perhaps the claim by Buhnerkempe and Westemeier ${ }^{11}$ of a North America recovery 
in numbers beginning immediately after passage of the Migratory Birds Convention Act in 1916 was somewhat premature. However, there was an appreciable recovery in Texas by the 1930s. ${ }^{43}$

In southern Saskatchewan, the eggs themselves were a delicacy, "often gathered for food in the same manner as lapwing plover eggs are in England."48 During the 1880 s near Wauchope, Saskatchewan, Upland Sandpipers were "so plentiful that they were regularly eaten by the early settlers and their eggs collected for the table.... their edible qualities are equal to those of the famous 'Plovers' eggs' of the English markets." ${ }^{45}$ Although the Upland Sandpiper is hardly one-tenth the mass of the Sharptailed Grouse, Thompson-Seton claimed that its eggs are equally large. ${ }^{54}$

Hunting pressure was also heavy on their "wintering grounds" on the pampas of Argentina. Our best information is from William Henry Hudson (1922), British naturalist and author, who was born near Buenos Aires in 1841 and remained on the pampas until 1874. Hudson said the Upland Sandpiper was "most abundant on the great level pampas where I had my home... one of the most frequently heard sounds on the pampas. ... they were solitary, sprinkled evenly over the entire country so that when out for a day on horseback I would flush one from the grass every few minutes ... I have spent whole weeks on horseback from dawn to dark without being for a day out of sight or sound of the bird." By 1920, "this sound ... is heard no more ... now on the list of the "next candidates for extinction." He indicated that this "incalculable destruction" had come about since the $1870 \mathrm{~s}^{33}$

Alexander Wetmore visited Argentina during the winter of 1920-21; among epicures there, the Upland Sandpiper had "inherited in part the name and reputation of the Eskimo Curlew and is sought constantly by gunners to supply that demand. The few that survive frequent the large estancias where they are secure ..." During late February and early March of 1921, Wetmore was amazed to find them still "a regular item on the bill of fare in the better class hotels and restaurants in the city of Buenos Aires" even though they were by then "difficult to secure as few were offered for sale." The birds were "so scarce that they were secured only by those gunners familiar with places where the Upland Plover alighted when in migration." 56 In Colombia, the Upland Sandpiper was not protected by law until 1940.'

Shooting and plowing of grassland were not the only reasons for the population decline in southeastern Saskatchewan. Pittman (1947) offered two additional explanations. The disproportionate increase in numbers of the American Crow with settlement contributed to depredation of Upland Sandpiper eggs and nestlings. And increased grazing by cattle and horses, increased numbers of grasshoppers, and intermittent drought, all diminished the protective grass cover on pastures. ${ }^{45}$

At Red Deer, Alberta, the Upland Sandpiper "decreased at an alarming rate" after Farley's arrival in 1892 and by 1931 , Farley knew of only a single pair in the entire Red Deer - Camrose area. ${ }^{22}$ During the first decade of the twentieth century, Upland Sandpipers had gone from "abundant" to "not common" at Prince Albert. ${ }^{23}$ Although still common at Wauchope about 1917, the species was obviously decreasing, and by 1946 Pittman found it had "completely disappeared from many places where I used to find them." 45 On grassy meadows north of Sheho the Upland Sandpiper suffered more than any other bird species from breaking of the land. It disappeared from the Sheho area entirely about 1927 , reappeared in smaller numbers in 1939 , but became scarce again after 1960.42

In 1917, when A.C. Bent visited the Quill Lakes, Saskatchewan, the Upland Sandpiper seemed to be adapting itself to the new conditions and nesting in cultivated fields. ${ }^{7}$ Yet in 1929, Bradshaw saw only a single pair at Quill Lakes, the first he had seen anywhere in southern Saskatchewan since 1925, in spite of extensive travel as game commissioner. ${ }^{9}$

Shooting has ceased in North America, but perhaps not fully in South America. Grasslands continue to fall to the plow, in part because mechanical rock pickers allow breaking of stony land previously not 
economical to farm. More recently, mowing machines have taken a frightful toll; Bolster (1990) witnessed two chicks killed by haying operations during two days, and presumed that all the young of eight broods perished, since he saw no young thereafter. Bolster suspected that the relatively new arrival in Colorado, the raccoon, may have been an additional factor. ${ }^{8}$ Similarly, the marked increase in the Red Fox in Saskatchewan since 1960 , is a potential but unstudied factor. $^{24,35}$

The current breeding distribution of the Upland Sandpiper reflects availability of open grassland habitat. The center of densest distribution is in North and South Dakota, where in selected areas Breeding Bird Surveys may encounter 50 to 60 individuals during 50 stops along a $39 \mathrm{~km}$ route. ${ }^{46}$ The most accurate random sampling method applied to an entire state is for North Dakota, where Igl and Johnson (pers. comm.) estimated a population of 235,195 Upland Sandpipers in the state in 1992 (Confidence Interval 165,684 to 306,705$).^{34}$ In 1967, maximum density in two biotic stratas in North Dakota reached 20 pairs per square mile (2.6 $\left.\mathrm{km}^{2}\right) \cdot 52$

In most other parts of their North American range, there are now only token numbers of Upland Sandpipers present. In Ontario, beginning in the early 19 th century, this species benefitted as forests were first cleared and replaced by pastures. ${ }^{12}$ In the eastern United States, housing development in recent decades has driven them from former breeding sites such as the Hempstead Plains on Long Island, leaving them restricted mainly to airports, including the John F. Kennedy airport. ${ }^{28}$ Confirmation that habitat is in short supply in the northeastern United States comes from its listing as endangered in five of these states, as threatened in four, and as special concern in one. ${ }^{27}$ A very few individuals persist in the western and mountain states. There is similar sparing use of high meadows in mountainous areas such as the Yukon. Peatlands in Quebec were used by 11 pairs. $^{13}$

On the Canadian prairies, this species becomes less common as one proceeds westward. Hales perceptively noted that "the more bare and open prairies of southern
Alberta and south-western Saskatchewan do not attract it." ${ }^{31}$ My personal observation is that appreciably fewer Upland Sandpipers are now present than during my boyhood 50 years ago. Some support for my perception is provided by the quantitative Breeding Bird Survey in Canada, 1966-1996. This shows downward trends of over $2 \%$ per year in grassland, and of $3.2 \%$ in parkland ("mixedwood plains"), but numbers are so small on most routes that this downward trend is not statistically significant. ${ }^{14}$ They have fared somewhat better in the United States, where there has been a statistically significant increase of $1.2 \%$ per year in Upland Sandpiper sightings on the survey routes, 1966- $1994 .{ }^{10}$

If our Canadian prairies are to maintain reasonable population levels of this distinctive species with its attractive whistle, we must preserve our remaining grasslands.

\section{Acknowledgments}

I thank Larry D. Igl, Northern Prairie Science Center, Jamestown, N.D., and Robert W. Nero, Manitoba Dept. of Natural Resources, Winnipeg, MB, for expert criticism.

1. ALLEN, F.H.. 1941. Conservation notes. Auk 58:607.

2. ALLEN J. A. 1874. Notes on the natural history of portions of Montana and Dakota. Proc. Boston Soc. Nat. Hist. 17:1-61.

3. AUGHEY, S. 1878. Notes on the nature of the food of the birds of Nebraska, Appendix 2, pp. 13-62, In: Annual report of the United States Entomological Commission for the year 1877 relating to the Rocky Mountain locust. Government printing office, Washington.

4. BARROWS, W. B. 1912. Michigan bird life. Michigan Agricultural College, East Lansing.

5. BATES, J. M. 1907. The Bartramian Sandpiper. Bird-Lore 9: 84.

6. BELCHER, M. 1980. Birds of Regina, revised edition. Sask. Nat. Hist. Soc. Spec. Publ. 12. 
7. BENT, A. C. 1929. Life Histories of North American shorebirds. Pp. 55-69 Bull. U. S. Natl. Mus. 146.

8. BOLSTER, D. C. 1990. Habitat use by the Upland Sandpiper in northeastern Colorado. M.S. thesis, University of Colorado. 104 pp.

9.BRADSHAW, F. 1929. From Saskatchewan. Oologist 46: 93-94.

10. BREEDING BIRD SURVEY. 1999. Trend results. Http://www.mbr-pwrc.usgs.gov/bbs/ htm96/t2610.htm

11. BUHNERKEMPE, J.E., and R.L. WESTEMEIER. 1988. Breeding biology and habitat of Upland Sandpipers on PrairieChicken sanctuaries in Illinois. Trans. III. Acad. Sci. 81:153-162.

12. CADMAN, M. D., P. F. J. EAGLES, and F. M. HELLEINER. 1987. Atlas of the breeding birds of Ontario. pp. 170-171. University of Waterloo Press, Waterloo, ON.

13. CALME, S., and S. HADDAD. 1996. Peatlands: a new habitat for the Upland Sandpiper, Bartramia longicauda, in eastern Canada. Can. Field-Nat. 110:326-330.

14. CANADIAN BIRD TRENDS DATABASE. 1999. Trends from the Canadian Breeding Bird Surveys.http://199.212.18.79/Birds/ Birdlnfo.cfm?id=2610.

15. CHRISTY, R. M. 1885. Notes on the birds of Manitoba. Zoologist, series 3, 9:121-133.

16. COOKE, W. W. 1897. The birds of Colorado. Colorado State Agric. Coll., Bull. 37, Fort Collins.

17. COOKE, W. W. 1914. Our shorebirds and their future. U.S. Dept. Agric. Yearbook. pp. 282-294.

18. COUBEAUX, E. 1900. Contributions to the natural history of the northwest territories. Ottawa Nat.14:24-31.

19. COUES, E. 1874. Birds of the northwest. Government Printing Office, Washington.
20. COUES, E. 1878. Field notes on birds observed in Dakota and Montana along the 49th parallel during the seasons of 1873 and 1874. Bull. U.S. Geol. and Geog. Survey Terr. 4:545-661.

21. CRIDDLE, N. 1929. Memoirs of the eighties. Can. Field-Nat. 43: 176-181.

22. FARLEY, F. L. 1932. Birds of the Battle River region. Institute of Applied Art, Edmonton.

23. FERRY, J. H. 1910. Birds observed in Saskatchewan during the summer of 1909. Auk 27:185-204.

24. FINLEY, K. 1996. The Red Fox invasion and other changes in wildlife populations in west-central Saskatchewan since the 1960s. Blue Jay 54:206-210.

25. FORBUSH, E. H. 1912. A history of game birds, wild fowl, and shore birds of Massacchusetts and adjacent states. Massachusetts State Board of Agriculture.

26. FORBUSH, E.H. 1939. A Natural History of American Birds. Houghton Mifflin, Boston.

27. FRENCH, T. W., and D. M. PENCE. 1996. Endangered, threatened and special concern animal species in the Northeastern states: a list of species recognized by state and federal law. U.S. Fish and Wildlife Service, Hadley, MA.

28. GARBER, S. D., S. CHEVALIER, and J. R. Cohen. 1997. Twenty-eight year study of Upland Sandpiper breeding population in New York. North Am. Bird Bander 22: 109-113.

29. GOSS, N.S. 1886. Birds of Kansas. Kansas Publishing House, Topeka.

30. GRAHAM, R. 1923. Bartramian Sandpiper going the Passenger Pigeon route. Oologist 40:105.

31. HALES, B. J. 1927. Prairie birds. MacMillan, Toronto.

32. HOY, P. R. 1853. Notes on the ornithology of Wisconsin. In: I.E. Lapham, Fauna and flora of Wisconsin. Trans. Wisc. State Agric. Soc. 2:341-364. 
33. HUDSON, W. H. 1922. A hind in Richmond Park. E.P. Dutton, New York, pp. 151-157.

34. IGL, L., and D.H. JOHNSON. 1997. Changes in breeding bird populations in North Dakota: 1967 to 1992-93. Auk 114:74-92.

35. JORDHEIM, S. 1995. Foxes in southcentral Saskatchewan. Blue Jay 43:232-233.

36. JUDD, E. T. 1917. List of North Dakota birds found in the Big Coulee, Turtle Mountains and Devils Lake Region. Elmer T. Judd, Cando, N.D., p. 13.

37. KRIDER, J. 1879. Forty years notes of a field ornithologist. Philadelphia: Joseph $\mathrm{H}$. Weston.

38. KUMLIEN, L., and N. HOLLISTER. 1903. The birds of Wisconsin. Bull. Wisc. Nat. Hist. Soc. 3:1-143.

39. MACKAY, G.H. 1891. The habits of the Golden Plover (Charadrius dominicus) in Massachusetts.

40. MACOUN, J. 1900. Catalogue of Canadian Birds, Part 1. Ottawa: S.E. Dawson, p. 178.

41. MCCHESNEY, C. E. 1879. Notes on the birds of Fort Sisseton, Dakota Territory. Bull. U.S. Geol. Surv. 5: 71-103.

42. NIVEN, W. 1973. The land, the birds: through 50 years in aspen parkland. Blue Jay 31:223-229.

43. OBERHOLSER, H.C. 1974. Birds of Texas. University of Texas Press, Austin.

44. OVER, W. H., and C. S. THOMS. 1921. Birds of South Dakota. South Dakota Geol. and Nat. Hist. Surv. Bull. 9. Vermilion.

45. PITTMAN, H. H. 1947. Plovers ... You see them - then you don't. Outdoor Canada May 1947:15-16.
46. PRICE, J., S. DROEGE, and A. PRICE. 1995. The summer atlas of North American birds.Academic Press, London and San Diego, p. 72.

47. QUILLIAM, H. R. 1973. History of the birds of Kingston, Ontario. Kingston Field Naturalists, Kingston, p.80.

48. RAINE, W. 1892. Bird-nesting in Northwest Canada. Hunter Rose, Toronto., p. 119.

49. ROBERTS, T. S. 1936. The birds of Minnesota. University of Minnesota Press, Minneapolis, pp. 486-490.

50. SCHORGER, A.W. 1955. The Passenger Pigeon: its natural history and extinction. University of Wisconsin Press, Madison.

51. SETON, E. T. 1909. Fauna of Manitoba, pp. 183-227, In: A handbook to Winnipeg and the Province of Manitoba. Local executive committee, British Assn. For the Advancement of Science, Winnipeg.

52. STEWART, R.E., and H.A. KANTRUD. 1972. Population estimates of breeding birds in North Dakota. Auk 89:766-788.

53. TAVERNER, P. A. 1919. The birds of Shoal Lake, Manitoba. Ottawa Nat. 32:157164.

54. THOMPSON [SETON], E. E. 1891. The birds of Manitoba. Proc. U. S. Natl. Mus. 13: 457-643.

55. WELLS, W. 1940. Some changes in forty years. Oologist 57:9-12.

56. WETMORE, A. 1926. Observations on the birds of Argentina, Paraguay, Uruguay, and Chile. U.S. Nat. Mus. Bull. 123. 